Беспалова О., Лянной Ю., Бугаєнко Т., Лянна О., Литвиненко В.

\title{
Конгітивно-змістовий компонент у структурі готовності майбутніх бакалаврів з фізичної терапії, ерготерапії до застосування фізкультурно-оздоровчих технологій у професійній діяльності
}

\author{
Сумський державний педагогічний університет імені А.С.Макаренка, \\ кафедра здоров'я, фізичної терапії, реабілітації та ерготерапії, м. Суми, Україна \\ i-ozon777@bigmir.net, lyo_ifk@ukr.net, bugaenkotv@ukr.net, lann_olga@ukr.net, lvitaline1982@gmail.com
}

\begin{abstract}
Беспалова О., Лянной Ю.,
Бугаенко Т., Лянная О., Литвиненко В.

Конгитивно-содержательный компонент в структуре готовности будущих бакалавров физической терапии, эрготерапии к применению физкультурно-оздоровительных технологий в профессиональной деятельности
\end{abstract}

Сумской государственный педагогический университет имени А.С. Макаренко, кафедра здоровья, физической терапии, реабилитации и эрготерапии, г. Сумы, Украина
Bespalova O., Liannoi Yu. Bugaenko T., Lianna O., Lytvynenko V. The congestive component in the structure of the readiness of future bachelors of physical therapy, ergotherapy for the application of physical and recreational technologies in professional activity Sumy State Pedagogical University Makarenko, Department of Health, Physical Therapy, Rehabilitation and Ergotherapy, Sumy, Ukraine

\section{Вступ}

Підготовка фізичних терапевтів, які здатні здійснювати висококваліфіковану допомогу в напрямку підвищення рівня здоров'я, компенсацію функційних порушень, профілактику рухових дисфункцій людини, була і залишається на сьогодні актуальною проблемою. Це пов'язано із нагальною потребою щодо впровадження змін у сфері охорони здоров'я у напрямку здійснення адекватного та своєчасного реабілітаційного втручання у відповідності до індивідуальних особливостей та потреб громадян, спрямованих розвиток, збереження, відновлення функціональних можливостей організму людини, забезпечення повноцінної життєдіяльності хворих і неповносправних, підвищення рівня якості життя населення України.

Згідно структурного аналізу готовність майбутніх бакалаврів 3 фізичної терапії та ерготерапії до застосування фізкультурно-оздоровчих технологій представлена наступними компонентами: мотиваційноціннісний, суб'єктний, когнітивно-змістовий та діяльнісний компоненти, що існують в єдності i взаємозв'язку. Враховуючи, що теоретичні знання $\epsilon$ основою для успішного вирішення професійних завдань засобами фізкультурно-оздоровчих технологій, важливим залишається питанням розкриття сутності конгітивнозмістового компоненту у формуванні означеного виду готовності.

Тому важливим питанням $\epsilon$ визначення ролі конгітивно-змістового компоненту у формуванні готовності фізичних терапевтів, ерготерапевтів до застосування фізкультурно-оздоровчих технологій у майбутній професійній діяльності.

Теоретичний аналіз науково-методичної літератури 3 дослідження проблем професійної підготовки фахівців 3 фізичної терапії (фізичної реабілітації) вказують на значну увагу науковців до вивчення різних іiї аспектів. Вивченню фундаментальних та прикладних основ їх професійної підготовки присвячені роботи Н.О. Бєлікової, Т.М. Бугері, Л.Б. Волошко, В.В. Крупи, В.О. Кукси, Ю.О. Лянного, Р.В. Маслова, Л.П. Сущенко, А.В. Фатівець та ін. Питання щодо структури готовності фахівців 3 фізичної терапії, ерготерапії до різних видів фахової діяльності висвітлені у роботах О. В. Бісмак (формування готовності до клінічної діяльності), Н.О. Бєлікової (формування готовності до здоров'язбережувальної діяльності), А. Фастівець (формування готовності до діагностичної діяльності), О. В. Базильчук (до роботи з відновлення здоров'я спортсменів) та ін.

Проте питання готовності фахівців 3 фізичної терапії, ерготерапії до застосування фізкультурнооздоровчих технологій за конгітивно-змістовим компонентом у науково-методичній літературі залишається нерозкритими.

Метою роботи $є$ обгрунтування змісту конгітивнозмістового компоненту готовності майбутніх бакалаврів 3 фізичної терапії та ерготерапії до застосування фізкультурно-оздоровчих технологій у професійній діяльності, визначити критерії, показники та психологопедагогічні методи оцінки рівня сформованості означеного виду готовності. 


\section{Об’скт та методи дослідження}

Об’єктом дослідження $є$ готовність майбутніх фахівців з фізичної терапії, ерготерапії за конгітивнозмістовим компонентом щодо застосування фізкультурнооздоровчих технологій у майбутній професійній діяльності.

Методи дослідження: теоретичний аналіз психологічної та спеціальної науково-методичної літератури 3 метою вивчення проблеми готовності майбутніх фахівців у галузі «охорона здоров'я»; структурний аналіз для розробки структури готовності та обгрунтування змісту конгітивно-змістового компоненту готовності майбутніх бакалаврів 3 фізичної терапії, ерготерапії до застосування фізкультурно-оздоровчих технологій у професійній діяльності; методи математичної статистики.

У дослідженні прийняли участь студенти 4-5 курсів спеціальності «Фізична терапія, ерготерапія» (фізична реабілітація) Сумського державного педагогічного університету імені А. С. Макаренка, Кам'янецьПодільського національного університету ім. Івана Огієнка, Національного університету «Чернігівський колегіум» ім. Т. Г. Шевченка, Бердянського державного педагогічного університету, Ужгородського національного університету.

\section{Результати дослідження та їх обговорення}

Аналіз дослідницьких позицій науковців щодо формування професійної готовності дає підстави виходити з розуміння готовності майбутнього бакалавра з фізичної терапії та ерготерапії до застосування фізкультурнооздоровчих технологій у професійній діяльності як складного динамічного особистісного утворення, яке забезпечує поточну реалізацію фізкультурно-оздоровчої професійної діяльності і полягає у оволодінні спеціальними знаннями фізкультурно-оздоровчих технологій та вміннями, пов'язаними з ними, прийомами та методами їх використання та передбачає наявність психологічних якостей, необхідних для фахівця з фізичної терапії та ерготерапії, $є$ підгрунтям для професійного самовдосконалення. Стан готовності до майбутньої професійної діяльності має складну динамічну структуру і представляє собою стійку єдність певних компонентів. При цьому усі компоненти структури готовності до професійної діяльності мають взаємозалежний, взаємопов'язаний і взаємопроникливий характер, завдяки чому і забезпечується цілісне узгодження характеристик людини як особистості і суб'єкта діяльності, а також успішність майбутньої професійної діяльності [7].

Враховуючи, що метою діяльності фахівця 3 фізичної терапії, ерготерапії на посаді є надання послуг приватним особам і населенню загалом для усунення, припинення або зменшення болю, відновлення функцій організму, досягнення нормального рівня здоров'я, фізичної самостійності та активності, оптимального фізичного стану та самопочуття осіб усіх вікових категорій 3 різноманітними порушеннями діяльності функціональних систем (Клименко, 2019), а головним засобом виступають фізичні вправи та їх комплекси, у нашому дослідженні була визначена та обгрунтована структура готовності майбутніх бакалаврів 3 фізичної терапії та ерготерапії до застосування фізкультурнооздоровчих технологій. Вона представлена чотирьохкомпонентною структурою: мотиваційноціннісний компонент характеризується наявністю у студентів системи цінностей, інтересів, потреб і мотивів засвоєння змісту теоретичних та процесуальнометодичних аспектів застосування фізкультурнооздоровчих технологій у професійної діяльності; суб'єктний компонент передбачає сформованість професійно важливих якостей особистості, які становлять основу для розвитку професійних умінь і навичок, спрямованих на практичну реалізацію фізкультурнооздоровчої діяльності; когнітивно-змістовий компонент передбачає сформованість у студентів знань теоретичних і методичних основ реалізації фізкультурно-оздоровчої роботи; діяльнісний компонент передбачає сформованість професійно важливих умінь і навичок, спрямованих на практичну реалізацію фізкультурно-оздоровчої діяльності. Наочно структура готовності представлена на рисунку 1.

Конгітивно-змістовий компонент визначається науковцями як один із фундаментальних у загальній структурі готовності будь-якого фахівця, оскільки він $є$ ключовим для його професійного становлення та саморозвитку, оволодіння новітніми технологіями та практиками [5], а фундаментальні знання передбачають перетворення структури та змісту наукового знання, встановлення таких зв'язків між навчальними дисциплінами, які дозволяють формувати в майбутніх спеціалістів цілісне уявлення про педагогічну діяльність, що підвищує ступінь застосування знань, активне їх використання [8].

Під когнітивним компонентом дослідники розглядають певний результат і рівень сформованості психологічних знань, психологічну грамотність, обізнаність про сутність психологічної складової майбутній професії тощо [11]. Він включає в себе розуміння поставлених завдань, знання способів їх вирішення та засобів досягнення мети, аналіз ймовірних змін ситуації - фактично це когнітивний аналіз ситуації і пошук способів вирішення завдання [7].

Розглядаючи зміст конгітивно-змістової складової готовності майбутніх фахівців в системі професійної підготовки, спираємося на сутність наукового пізнання у сфері професійної освіти, яке «складає методологічну основу конгітивно-змістових процесів усіх рівнів i спрямувань» [10]. Адже саме наукове пізнання у сфері професійної освіти являє собою складний суперечливий процес відтворення знань, які створюють цілісну розвивальну систему понять, теорій, гіпотез, законів; науковий пошук містить педагогічну практику, а також передбачає узагальнення системи фактів, поглиблює i розвиває теоретичні положення та уточнюе базові поняття [6].

При визначенні складових конгітивно-змістового компоненту у нашому дослідження ми дотримувалися 
думки О.А. Абдуліної, яка у структурі знань виділяє наступні елементи: 1) знання фундаментальних ідей, концепцій, законів та закономірностей розвитку явищ; 2) знання провідних педагогічних теорій, основних категорій та понять; 3) знання основоположних педагогічних фактів; 4) прикладні знання про загальну методику навчання та виховання тих, хто навчається [1].

\section{Структура готовності майбутніх бакалаврів з фізичної терапії та ерготерапії до застосування фізкультурно-оздоровчих технологій у професійній діяльності}
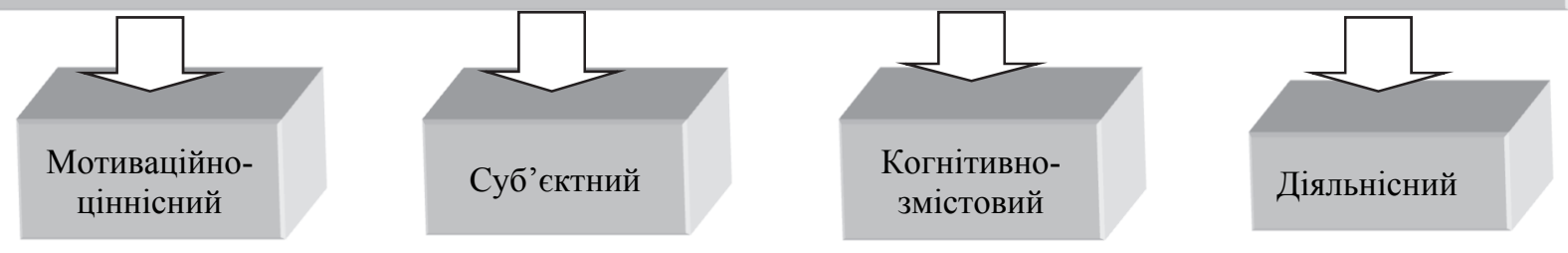

Рис. 1. Схематичне зображення компонентного складу готовності майбутніх бакалаврів з фізичної терапії та ерготерапії до застосування фізкультурно-оздоровчих технологій у професійній діяльності

Отже, на нашу думку, когнітивно-змістовий компонент готовності майбутніх бакалаврів з фізичної терапії, ерготерапії до застосування фізкультурнооздоровчих технологій передбачає, сформованість у студентів знань теоретичних і методичних основ реалізації фізкультурно-оздоровчої роботи, оскільки саме вони $є$ підгрунтям для кваліфікованого використання фізкультурно-оздоровчих технологій в практичній діяльності. У процесі навчання бакалаври отримують знання 3 циклів загальної та професійної підготовки. Теоретичний базис закладається у процесі вивчення дисциплін з циклів загальної та професійної підготовки: «Теорія і методика фізичного виховання», «Біомеханіка», «Основи фізичної реабілітації», «Теорія і технології оздоровчо-рекреаційної рухової активності», «Лікувальна фізична культура», «Функціональний фітнес», «Фізіологія рухової активності», «Фітнес-програми аеробного та силового спрямування», «Тренування рухової активності хворих та неповносправних» [2].

При вивченні означених дисциплін майбутні бакалаври з фізичної терапії та ерготерапії засвоюють види фізкультурно-оздоровчих технологій, їх характеристику та особливості практичного впровадження; особливості планування реабілітаційного втручання із застосуванням фізкультурно-оздоровчих технологій; методичні особливості виконання фізичних вправ;; методи організації занять різної спрямованості; способи дозування фізичного навантаження в залежності від вікової та нозологічної групи; знання про тонізуючу, трофічну дію фізичних вправ, їх вплив на функціональний стан пацієнта/клієнта та перебіг обмінних процесів.

Таким чином, когнітивно-змістовий компонент готовності майбутніх бакалаврів 3 фізичної терапії, ерготерапії до застосування фізкультурно-оздоровчих технологій становлять професійно-фахові знання, які умовно можна об'єднати у такі групи: психологопедагогічні (про зміст, структуру, принципи, методи, засоби фізкультурно-оздоровчих технологій; про початок, підтримання та завершення діалогу під час професійного спілкування із співрозмовниками (членами мультидисциплінарної команди, пацієнтами / клієнтами, родичами хворих та членами їх сімей) та у досягненні конкретних комунікативно-професійних цілей; медикобіологічні (про анатомо-фізіологічні особливості функціонування організму людини в стані спокою, під час фізичного навантаження, у процесі відновлення та при наявних функціональних обмеженнях); технологічні (про техніку виконання фізичних вправ, про методи визначення оптимального рівня рухової активності; про діагностичні методи, які дозволяють укласти реабілітаційний профіль за показниками фізичного розвитку, фізичної підготовленості, функціонального стану, існуючих функціональних обмежень, психоемоційного статусу тощо) [2].

3 метою діагностики сформованості готовності за конгітивно-змістовим компонентом нами були обрані відповідні критерії і показники, а також сформований діагностичний інструментарій.

Діагностика сформованості готовності майбутніх бакалаврів 3 фізичної терапії та ерготерапії до застосування фізкультурно-оздоровчих технологій за конгітивно-змістовим компонентом здійснювалася за теоретичним критерієм, який передбачає засвоєння професійно-орієнтованих знань за обсягом, якістю, практичною спрямованістю, відповідністю кваліфікаційним вимогам.

3 цією метою в експериментальному дослідженні було використано розроблені нами тести, спрямовані на визначення рівня теоретико-методичних знань щодо особливостей застосування фізкультурно-оздоровчих технологій у оздоровчій, профілактичній, реабілітаційній діяльності. Тестові завдання передбачали чотири варіанти відповідей з одним вірним. Результатом тестування стала загальна сума балів за правильні відповіді, згідно якої студенти набували високого, середнього та низького рівня оволодіння фаховими знаннями щодо процесуальнометодичних аспектів застосування фізкультурнооздоровчих технологій у різних видах професійної діяльності. Приклади розроблених тестів наведено у $[2,3]$. 
Зразок тестових завдань:

1. 3 якої причини людина відчуває м'язовий біль, що з'являється через 12 годин після навантаження:

a. накопичення продуктів окислення речовин;

b. накопичення рідини;

c. порушення цілісності окремих м'язових волокон;

d. накопичення молочної кислоти?

2. Методичними прийомами дозування фізичного навантаження під час оздоровчого (реабілітаційного, тренувального) заняття є:

а. кількість повторень обраної вправи;

b. вибір вихідного положення;

c. амплітуда рухів

d. усі відповіді вірні?

У відповідності до отриманих у ході проведення розробленого нами тестування студенти набувають низького, середнього та високого рівня готовності за теоретичним критерієм. Ці рівні мають наступні характеристики.

Так, низький рівень готовності до застосування фізкультурно-оздоровчих технологій за означеним показником у професійній діяльності характеризується несформованістю понятійного апарату, недостатнім рівнем теоретико - методичної підготовленості у напрямку застосування фізкультурно-оздоровчих технологій у різних ситуаціях професійної діяльності фізичного терапевта, ерготерапевта; складністю в узагальненні та систематизації навчальної інформації, a отже i неможливістю встановлювати міжпредметні зв'язки для отримання системних професійноорієнтованих знань.

Середній рівень готовності майбутніх бакалаврів 3 фізичної терапії та ерготерапії до застосування фізкультурно-оздоровчих технологій вказує достатній обсяг систематизованих відповідних фаху теоретикометодичних знань $з$ фізкультурно-оздоровчих технологій для кваліфікованого здійснення професійній діяльності, які дають можливість студентам аналізувати віддалені або завершені процеси реабілітаційного втручання та переносити набуті знання для вирішення іншої професійної ситуації.

Високий рівень готовності характеризується наявністю сформованих грунтовних, систематизованих під час спеціально організованого освітнього процесу в вищому навчальному закладі професійно-орієнтованих знань щодо процесуально-методичних аспектів застосування засобів фізкультурно-оздоровчих технологій у реабілітаційній, оздоровчій, профілактичній та інших видах професійної діяльності у роботі 3 пацієнтами / клієнтами різних вікових та нозологічних груп.

На констатувальному етапі дослідження були залучені 180 студентів 4-5 курсів спеціальності «Фізична терапія, ерготерапія» (фізична реабілітація) Сумського державного педагогічного університету імені А. С. Макаренка, Кам'янець-Подільського національного університету ім. Івана Огієнка, Національного університету «Чернігівський колегіум» ім. Т. Г. Шевченка, Бердянського державного педагогічного університету, Ужгородського національного університету. Наочні результати проведеного тестування представлені на рисунку 2.

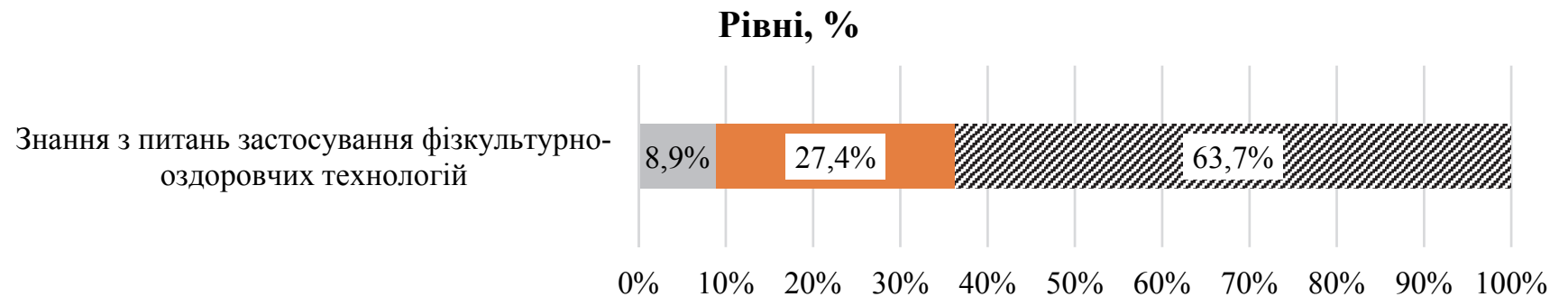

\begin{tabular}{|l|c|}
\cline { 2 - 2 } \multicolumn{1}{c|}{} & Знання з питань застосування фізкультурно-оздоровчих технологій \\
\hline Високий рівень & $8,9 \%$ \\
\hline Середній рівень & $27,4 \%$ \\
\hline$\approx$ Низький рівень & $63,7 \%$ \\
\hline
\end{tabular}

Рис. 2. Рівні сформованості професійних знань з питань щодо застосування фізкультурно-оздоровчих технологій

Отримані дані свідчать, що найбільшу групу (79 осіб) респондентів складають студенти, які мають низький рівень знань щодо теорії і методики застосування фізкультурно-оздоровчих технологій у майбутній професійній діяльності, що складає 63,7\% від загальної їх кількості. Середній рівень фахових знань показали 34 фахівці, що відповідає 27,4\% респондентів. Лише $8,9 \%$ від загальної кількості виявили високий рівень теоретичних знань 3 питань застосування фізкультурно-оздоровчих технологій у професійній діяльності фізичного терапевта, ерготерапевта. Це вказує на суттєві недоліки в організації навчально-виховного процесу студентів у напрямку формування їх готовності до застосування даних технологій, що потребує його удосконалення.

Значні труднощі у студентів виникають при відповідях на запитання, що вимагають установлення міжпредметних зв'язків; визначення фахової термінології i понять; урахування показань та протипоказань до 
застосування фізичних вправ; вибору спеціальних фізичних вправ для пацієнтів / клієнтів, які мають в анамнезі різноманітні порушення та захворювання; знань показників толерантності до фізичних навантажень тощо.

Найкращі результати зафіксовано при відповіді на практично-орієнтовані питання стосовно форм та правил організації фізкультурно-оздоровчих тренувань; знань структурних компонентів фітнес-програм тощо.

Таким чином, підсумовуючи отримані в ході дослідження результати, варто зазначити, що якісне виконання професійних функцій і кваліфіковане вирішення професійних задач фізичним терапевтом, ерготерапевтом у напрямку застосування фізкультурно-оздоровчих технологій забезпечується шляхом оволодіння на високому рівні психолого-педагогічними та професійнопрофільованими знаннями у процесі їх професійної підготовки, а також уміннями впроваджувати отримані в ході навчально-педагогічного процесу теоретичні знання у професійну діяльність, трансформувати у відповідності до професійних умов і обставин, творчо переосмислювати поряд із набуттям практичного досвіду.

Перспективи подальших досліджень вбачаємо у розробці авторської моделі формування готовності майбутніх бакалаврів з фізичної терапії, ерготерапії до застосування фізкультурно-оздоровчих технологій у майбутній професійній діяльності.

\section{Висновки}

Таким чином встановлено, що фізкультурнооздоровчі технології є одним із головних інструментів практичної діяльності фізичного терапевта, ерготерапевта (фізичного реабілітолога) та засобом впливу на стан здоров'я, фізичний розвиток, функціональний стан та фізичну працездатність осіб різних вікових та нозологічних груп населення. У результаті грунтовного аналізу науково-методичної літератури щодо структури готовності майбутніх фахівців 3 фізичної терапії, ерготерапії (фізичної реабілітації) до різних видів фахової діяльності та основних ії компонентів нами була визначена та представлена структура готовності майбутніх бакалаврів з фізичної терапії, ерготерапії до застосування фізкультурно-оздоровчих технологій у майбутній професійній діяльності. Враховуючи, що теоретичні знання $є$ підгрунтям для кваліфікованого використання фізкультурно-оздоровчих технологій в практичній діяльності, нами було охарактеризовано конгітивнозмістовий компонент готовності, який окреслює професійно-фахові знання майбутнього фахівця. Критерієм конгітивно-змістового компоненту обрано теоретичний критерій, який відображує рівень сформованості відповідних знань за обсягом, якістю, практичною спрямованістю, відповідністю кваліфікаційним вимогам фахівця 3 фізичної терапії, ерготерапії. Оцінка рівня сформованості професійнопрофільованих знань відбувалася за допомогою розроблених нами тестових завдань, які включали питання iз дисциплін медико-біологічного (анатомія 3 основами біології, фізіологія людини, вікова фізіологія, фізіологія рухової активності, біомеханіка, інструментальні методи діагностики) та професійно-орієнтованого блоків (вступ до спеціальності з основами реабілітації, лікувальна фізична культура, функціональний фітнес, фітнес програми аеробного та силового спрямування, оздоровчорекреаційні технології та ін.).

\section{Література}

1. Абдуллина ОА. Общепедагогическая подготовка учителя в системе высшего педагогического образования: Для пед. спец. высш. учеб. заведений. - 2-е изд., перераб. и доп. - М.: Просвещение; 1990. 141 с.

2. Беспалова ОО. Методичні рекомендації до практичних занять з навчальної дисципліни «Функціональний фітнес». Суми; 2019. 60 с.

3. Беспалова ОО. Фітнес-програми силової та аеробної спрямованості : методичні рекомендації. Суми; 2018. $63 \mathrm{c}$.

4. Беспалова ОО. Сутність та структурні компоненти готовності майбутніх бакалаврів з фізичної терапії, ерготерапії до застосування фізкультурно-оздоровчих технологій. Педагогічні науки: теорія, історія, інноваційні технології. 2019; 5(89): 269-280.

5. Білоусова Л., Житенева Н. Компоненти готовності майбутніх учителів природничо-математичних дисциплін до застосування технологій візуалізації у предметно-професійній діяльності. Наукові записки. Серія: педагогіка. 2018; 3: 80-87.

6. Дубасенюк ОА. Наукові засади професійно-педагогічної підготовки студентів. Вісник Глухівського державного педагогічного університету. Серія: Педагогічні науки. 2010; 15(1): 3-8.

7. Дудукалова ОС. Сутність та структура готовності до професійної діяльності майбутніх інженерів економічного профілю. Збірник наукових праць Кам'янець-Подільського національного університету ім. Івана Огієнка. Серія : Педагогічна. 2016; 22:138-140. е Режим доступу: http://nbuv.gov.ua/UJRN/znpkp_ped_2016_22_45

8. Клак IЄ. Критерії, показники та рівні сформованості професійної комунікативної компетентності майбутніх учителів англійської мови. Наукові записки Національного університету «Острозька академія». Серія : Філологічна. 2017; 65 (1): 165-168. Режим доступу: http://nbuv.gov.ua/UJRN/Nznuoaf_2017_64\%281\%29_60

9. Курнишев ЮА. Педагогічні умови професійного саморозвитку майбутніх учителів фізичної культури : дис. ... канд. пед. наук. Київ; 2017. 249 с. 
10. Опалюк ТЛ. Конгітивно-змістова компонента соціальної рефлексії майбутнього вчителя. Науковий часопис НПУ імені М. П. Драгоманова. 2018; 61: 218-222.

11. Полозенко ОВ. Модель формування психологічної готовності майбутніх фахівців аграрної галузі до професійної діяльності. Проблемы современного педагогического образования. Серия: Педагогика и психология. 2014; 46 (4): 213-220.

\section{References}

1. Abdullyna OA. Obshchepedahohycheskaia podhotovka uchytelia v systeme vissheho pedahohycheskoho obrazovanyia: Dlia ped. spets. vissh. ucheb. zavedenyi [General pedagogical preparation of the teacher in the system of higher pedagogical education: For ped. spec. higher textbooks routine]. Moscow; 1990. 141 s.[in Russian].

2. Bespalova, O. O. (2018). Fitnes-prohramy sylovoi ta aerobnoi spriamovanosti : metodychni rekomendatsii [Power and Aerobic Fitness Programs: Guidelines]; Sumy. 63 s. [in Ukrainian].

3. Bespalova, OO. Sutnist ta strukturni komponenty hotovnosti maibutnikh bakalavriv z fizychnoi terapii, erhoterapii do zastosuvannia fizkulturno-ozdorovchykh tekhnolohii [The essence and structural components of the readiness of future bachelors in physical therapy, ergotherapy to the application of fitness and health technologies]. Pedahohichni nauky: teoriia, istoriia, innovatsiini tekhnolohii : Pedagogical Sciences: Theory, History, Innovative Technologies. 2019; 5 (89): $269-280$. [in Ukrainian].

4. Bespalova, OO. Metodychni rekomendatsii do praktychnykh zaniat z navchalnoi dystsypliny «Funktsionalnyi fitnes»[Methodological recommendations for practical training in the course «Functional fitness»]. Sumy; 2019.60 s. [in Ukrainian].

5. Bilousova L., Zhyteneva N. Komponenty hotovnosti maibutnikh uchyteliv pryrodnycho-matematychnykh dystsyplin do zastosuvannia tekhnolohii vizualizatsii u predmetno-profesiinii diialnosti [Components of the readiness of future teachers of natural and mathematical disciplines to the use of visualization technologies in the subject-professional activity]. Naukovi zapysky. Seriia: pedahohika : Proceedings. Series: Pedagogy. 2018; 3: 80-87. [in Ukrainian].

6. Dubaseniuk OA. Naukovi zasady profesiino-pedahohichnoi pidhotovky studentiv [Scientific bases of professional and pedagogical preparation of students]. Visnyk Hlukhivskoho derzhavnoho pedahohichnoho universytetu. Seriia: Pedahohichni nauky : Bulletin of the Hlukhiv State Pedagogical University. Series: Pedagogical Sciences. 2010; 15(1): 3-8. [in Ukrainian].

7. Dudukalova OS. Sutnist ta struktura hotovnosti do profesiinoi diialnosti maibutnikh inzheneriv ekonomichnoho profiliu [The essence and structure of professional engineers' readiness for professional activity] Zbirnyk naukovykh prats Kamianets-Podilskoho natsionalnoho universytetu im. Ivana Ohiienka. Seriia : Pedahohichna : Collection of scientific works of Kamenets-Podilsky National University Ivana Ogienko. Series: Pedagogical. 2016; 22: 138-140. [in Ukrainian]. http://nbuv.gov.ua/UJRN/znpkp_ped_2016_22_45

8. Klak IYe. Kryterii, pokaznyky ta rivni sformovanosti profesiinoi komunikatyvnoi kompetentnosti maibutnikh uchyteliv anhliiskoi movy [Criteria, indicators and levels of professional communication competence of future English teachers]. Naukovi zapysky Natsionalnoho universytetu «Ostrozka akademiia». Seriia : Filolohichna : Scientific notes of the Ostroh Academy National University. Series: Philological. 2017; 64(1): 165-168. [in Ukrainian].

9. Kurnyshev YuA. Pedagogical conditions of professional self-development of future teachers of physical culture [Pedahohichni umovy profesiinoho samorozvytku maibutnikh uchyteliv fizychnoi kultury]. Kiev; 2017.249 s. [in Ukrainian].

10. Opaliuk TL. Konhityvno-zmistova komponenta sotsialnoi refleksii maibutnoho vchytelia [The contingent and meaningful component of the future teacher's social reflection]. Naukovyi chasopys imeni M. P. Drahomanova : Dragomanov Scientific Journal. 2018; 61: 218-222. [in Ukrainian].

11. Polozenko OV. Model formuvannia psykholohichnoi hotovnosti maibutnikh fakhivtsiv ahrarnoi haluzi do profesiinoi diialnosti [Model of formation of psychological readiness of future specialists of agrarian industry for professional activity]. Problemi sovremennoho pedahohycheskoho obrazovanyia. Seryia: Pedahohyka y psykholohyia : Problems of modern pedagogical education. Series: Pedagogy and Psychology. 2014; 46(4): 213-220. [in Russian].

Дата надходження рукопису до редакції: 02.03.2020 p.

Мета дослідження є обгрунтування змісту конгітивно-змістового компоненту готовності майбутніх бакалаврів з фізичної терапії та ерготерапії до застосування фізкультурно-оздоровчих технологій у професійній діяльності, визначення критеріїв, показників та методи оцінки рівня сформованості до означеного виду готовності.

Матеріали та методи. Дослідження було проведено на базі Сумського державного педагогічного університету імені А. С. Макаренка, Кам'янець-Подільського національного університету ім. Івана Огієнка, Національного університету «Чернігівський колегіум» ім. Т. Г. Шевченка, Бердянського державного педагогічного університету, Ужгородського національного університету, до якого були залучені студенти 4-5 курсів спеціальності «Фізична терапія, ерготерапія» (фізична реабілітація). Для досягнення означеної мети нами були використані наступні методи 
дослідження: теоретичний аналіз психологічної та спеціальної науково-методичної літератури 3 метою вивчення проблеми готовності майбутніх фахівців у галузі «охорона здоров'я»; структурний аналіз для розробки структури готовності та обгрунтування змісту конгітивно-змістового компоненту готовності майбутніх бакалаврів 3 фізичної терапії, ерготерапії до застосування фізкультурно-оздоровчих технологій у професійній діяльності; методи математичної статистики.

Результати та обговорення. Підготовка фахівців з фізичної терапії, ерготерапії до кваліфікованого виконання професійних функцій у напрямку підвищення рівня здоров'я, компенсацію функційних порушень, профілактику рухових дисфункцій людини засобами фізкультурно-оздоровчих технологій була і залишається актуальною проблемою. Ураховуючи сферу та особливості практичної діяльності фахівців з фізичної терапії, ерготерапії, у статті розкрито сутність конгітивно-змістового компоненту готовності, який окреслює професійно-фахових знань майбутнього фахівця у напрямку застосування фізкультурно-оздоровчих технологій при виконанні професійних функцій та вирішенні професійних завдань. Критерієм конгітивно-змістового компоненту обрано теоретичний критерій, який відображує рівень сформованості відповідних знань за обсягом, якістю, практичною спрямованістю, відповідністю кваліфікаційним вимогам фахівця з фізичної терапії, ерготерапії. Відповідно до критерію та показників обрано діагностичний інструментарій для оцінювання якості знань та визначення рівнів сформованості готовності майбутніх бакалаврів 3 фізичної терапії, ерготерапії до застосування фізкультурно-оздоровчих технологій за обраним компонентом. Оцінка рівня сформованості знань відбувалася за допомогою розроблених нами тестових завдань, зміст яких був спрямований на з'ясування знань з теорії і методики застосування фізкультурно-оздоровчих технологій у сфері фізіотерапевтичної (реабілітаційної) діяльності та інших суміжних дисциплін, поєднаних міждисциплінарними зв'язками.

Ключові слова: фізична терапія; ерготерапія; готовність; структура готовності; компоненти готовності; критерії; показники; когнітивний критерій; теоретичні знання; тестування.

Целю исследования является обоснование содержания конгитивно-содержательного компонента готовности будущих бакалавров физической терапии и эрготерапии к применению физкультурно-оздоровительных технологий в профессиональной деятельности, определение критериев, показателей и методы оценки уровня формирования к указанному виду готовности.

Материалы и методы. Исследование было проведено на базе Сумского государственного педагогического университета имени А. С. Макаренко, Каменец-Подольского национального университета им. Ивана Огиенко, Национального университета «Черниговский коллегиум» им. Т. Г. Шевченко, Бердянского государственного педагогического университета, Ужгородского национального университета, к которому были привлечены студенты 45 курсов специальности «Физическая терапия, эрготерапия» (физическая реабилитация). Для достижения указанной цели нами были использованы следующие методы исследования: теоретический анализ психологической и специальной научно-методической литературы с целью изучения проблемы готовности будущих специалистов в области «здравоохранение»; структурный анализ для разработки структуры готовности и обоснование содержания конгитивносодержательного компонента готовности будущих бакалавров физической терапии, эрготерапии к применению физкультурно-оздоровительных технологий в профессиональной деятельности; методы математической статистики.

Результаты и обсуждение. Подготовка специалистов по физической терапии, эрготерапии к квалифицированному выполнению профессиональных функций в направлении повышения уровня здоровья, компенсацию функциональных нарушений, профилактику двигательных дисфункций человека средствами физкультурно-оздоровительных технологий была и остается актуальной проблемой. Учитывая сферу и особенности практической деятельности специалистов по физической терапии, эрготерапии, в статье раскрыта сущность конгитивно-содержательного компонента готовности, который определяет профессионально-профессиональных знаний будущего специалиста в направлении применения физкультурно-оздоровительных технологий при выполнении профессиональных функций и решении профессиональных задач. Критерием конгитивно-содержательного компонента избран теоретический критерий, который отображает уровень сформирования соответствующих знаний по объему, качеству, практической направленности, соответствием квалификационным требованиям специалиста по физической терапии, эрготерапии. В соответствии с критерием и показателей избран диагностический инструментарий для оценки качества знаний и определения уровней сформирования готовности будущих бакалавров физической терапии, эрготерапии к применению физкультурно-оздоровительных технологий по выбранному компонентом. Оценка уровня сформирования знаний происходила с помощью разработанных нами тестовых заданий, содержание которых было направлено на выяснение знаний по теории и методики применения физкультурно-оздоровительных технологий в сфере физиотерапевтической (реабилитационной) деятельности и других смежных дисциплин, объединенных междисциплинарными связями.

Ключевые слова: физическая терапия; эрготерапия; готовность; структура готовности; компоненты готовности; критерии; показатели; когнитивный критерий; теоретические знания; тестирования.

The purpose of the study is to substantiate the content of the congenital content component of the readiness of future bachelors in physical therapy and ergotherapy to the application of physical and recreational technologies in professional activity, to define criteria, indicators and methods of assessing the level of fitness for a particular type of readiness. 
Materials and methods. The study was conducted at the Sumy State Pedagogical University named after AS Makarenko, Kamyanets-Podilsky National University. Ivan Ogienko, National University "Chernihiv College" them. TG Shevchenko, Berdyansk State Pedagogical University, Uzhgorod National University, to which 45 courses of the specialty "Physical therapy, ergotherapy" (physical rehabilitation) were involved. To achieve this goal, we used the following research methods: theoretical analysis of psychological and specialized scientific and methodological literature in order to study the problem of future health professionals' readiness; structural analysis for the development of the readiness structure and substantiation of the content of the contingent content component of the readiness of future bachelors in physical therapy, ergotherapy for the application of fitness and health technologies in professional activity; methods of mathematical statistics.

Results and discussion. Training of specialists in physical therapy, ergotherapy for the professional performance of professional functions in the direction of improving the level of health, compensation of functional disorders, prevention of motor dysfunction of the person by means of physical and health technologies has been and remains an urgent problem. Taking into account the sphere and peculiarities of practical activity of specialists in physical therapy, ergotherapy, the article reveals the essence of the congressive-content component of readiness, which outlines the professional and professional knowledge of the future specialist in the direction of the use of physical and health technologies in the performance of professional professions and decisions. The criterion of the contingent-content component is the theoretical criterion, which reflects the level of formation of relevant knowledge in terms of volume, quality, practical orientation, compliance with the qualification requirements of a specialist in physical therapy, ergotherapy. According to the criteria and indicators, a diagnostic tool was selected to assess the quality of knowledge and determine the levels of preparedness of future bachelors in physical therapy, ergotherapy for the use of physical and health technologies by the selected component. Assessment of the level of knowledge development was carried out with the help of our developed test tasks, the content of which was aimed at clarifying knowledge of the theory and methods of application of physical and health technologies in the field of physical therapy (rehabilitation) activity and other related disciplines, combined with interdisciplinary.

Key words: physical therapy; ergotherapy; readiness; structure of readiness; readiness components; criteria; Indexes; cognitive criteria; theoretical knowledge; testing.

Конфлікт інтересів: відсутній.

Conflicts of interest: authors have no conflicts of interest to declare.

\section{Відомості про авторів}

Беспалова Оксана Олександрівна - кандидат педагогічних наук, ст. викладач кафедри здоров’я, фізичної терапії, реабілітації та ерготерапії Сумського державного педагогічного університету ім. А. С. Макаренка; вул. Роменська, 87, м. Суми, Україна, 40002.

+380 (99) 363-27-97, ORCID 0000-0002-0081-6021, i-ozon777@bigmir.net.

Лянной Юрій Олегович - доктор педагогічних наук, професор кафедри здоров’я, фізичної терапії, реабілітації та ерготерапії Сумський державний педагогічний університет імені А.С. Макаренка; вул. Роменська, 87, м. Суми, Україна, 40002.

+380 (95) 168-18-50, ORCID 0000-0003-2332-8794, lyo_ifk@ukr.net.

Бугаєнко Тетяна Вікторівна - кандидат педагогічних наук, ст. викладач кафедри здоров’я, фізичної терапії, реабілітації та ерготерапії Сумський державний педагогічний університет імені А.С. Макаренка; вул. Роменська, 87, м. Суми, Україна, 40002.

+380 (66) 955-91-29, ORCID 0000-0003-3745-0593, bugaenkotv@ukr.net.

Лянна Ольга Володимирівна - кандидат педагогічних наук, ст. викладач кафедри здоров'я, фізичної терапії, реабілітації та ерготерапії Сумський державний педагогічний університет імені А.С. Макаренка; вул. Роменська, 87, м. Суми, Україна, 40002.

+380 (95) 383-14-94, ORCID 0000-0002-4467-7166, lann_olga@ukr.net.

Литвиненко Віталіна Анатоліївна - кандидат педагогічних наук, ст. викладач кафедри здоров’я, фізичної терапії, реабілітації та ерготерапії Сумський державний педагогічний університет імені А.С. Макаренка; вул. Роменська, 87, м. Суми, Україна, 40002.

+380 (99) 212-81-44, ORCID 0000-0002-9790-289X, lvitaline1982@gmail.com. 